\title{
Managing Capital Inflows: \\ Eastern Europe in an Asian Mirror ${ }^{1}$ \\ Barry Eichengreen and Omar Choudhry \\ University of California, Berkeley \\ May 2005
}

\section{Introduction}

The accession economies of Eastern Europe and the rapidly industrializing economies of East Asia are face similar problems of managing capital inflows. ${ }^{2}$ Both regions are attractive destinations for foreign investment by virtue of their relatively low labor costs, which make them competitive export platforms, and their rapidly growing domestic markets. The magnitude of financial flows to the two regions is quite similar: Institute of International Finance forecasts for 2005 are for private financial flows of \$122 billion to Emerging Europe and \$134 billion to Emerging Asia. ${ }^{3}$ Both regions maintain relatively stable exchange rates against their principal trading partners, Eastern Europe vis-à-vis the EU15 and East Asian vis-à-vis the United States. ${ }^{4}$ Both have capital market regimes that are substantially open to financial flows.

At the same time, outcomes in the two regions are visibly different. In Emerging Europe savings are insufficient to underwrite domestic investment; in most years the investment-savings gap translates into a current account deficit that is financed by capital inflows. (This was the case in 2003 and is again forecast to be the case in 2005, although Emerging Europe's current account was actually in modest surplus in 2004.) In

\footnotetext{
${ }^{1}$ Prepared for the Turkish Central Bank/Center for European Integration Studies conference on Macroeconomic Policies for EU Accession, Ankara, 6-7 May 2005.

${ }^{2}$ Here and throughout the paper we are referring not just to the current crop of accession economies but also to the next wave - that is, countries like Bulgaria, Romania and Turkey. In the case of Emerging Asia, we include China as well as the Newly Industrializing Economies and the principal ASEAN countries.

${ }^{3}$ See Institute of International Finance (2005). Given the magnitude of the respective regional economies, this means that private inflows scaled by regional GDP are greater in Emerging Europe.

${ }^{4}$ And the associated dollar zone.
} 
Emerging Asia, in contrast, savings more than suffice to finance the region's investment. The result is a current account surplus, requiring private capital inflows to be more than absorbed into foreign reserves if they are not to produce unacceptable inflationary pressure. ${ }^{5}$ Thus, in 2004 reserve accumulation in Emerging Asia was roughly twice the private capital inflow, where in Emerging Europe it was only half. In 2005 reserve accumulation in Emerging Asia is again forecast to be twice the private capital inflow whereas in Emerging Europe it is forecast to fall to less than a third. ${ }^{6}$ (See Table 1.)

Understanding the problems associated with these outcomes and the policies that should be pursued in response requires first understanding the sources of these divergent patterns. The two regions differ in four relevant respects. First, compared to Emerging Europe, Emerging Asia, which is dominated by China, is even further behind the highincome countries and thus has even more scope for rapid growth. Fast-growing economies tend to be characterized by high private savings rates as residents attempt to capture the returns associated with the catch-up process. ${ }^{7}$ Second, demographics have been conducive to higher savings rates in Emerging Asia - countries with higher old-age dependency ratios like those of Emerging Europe tending to save less - although this contrast should eventually disappear as a result of Asia's demographic transition (and China's one-child policy). Third, Emerging Asian economies with some exceptions have displayed greater fiscal discipline: high rates of public dissaving have not neutralized

\footnotetext{
${ }^{5}$ As we will see in Section 2, the reality is somewhat more complex, although the preceding is still a useful way of characterizing the contrast. In addition, there is the question of what elements of the preceding account are fundamentally exogenous. The preceding paragraph essentially characterizes the current account and the capital flow as exogenous and the reserve accumulation as the endogenous balancing item. At some level, of course, all three elements are endogenous and depend on deeper structural and behavioral characteristics like those about to be described.

${ }^{6}$ Where the forecasts again are those of the Institute of International Finance.

${ }^{7}$ The association of income growth with savings rates is theoretically ambiguous, since the income and substitution effects work in opposite directions. Empirically, the evidence is strongly supportive of the view that the two variables are positively correlated. See e.g. Bosworth (1993).
} 
high private savings. Lastly, Emerging Asian countries, perceiving current account deficits as a source of vulnerability since the crisis of 1997-8, have been willing to accept less investment than they might have been able to sustain otherwise in order to limit their dependence on foreign capital, short-term foreign capital in particular. ${ }^{8}$ Rightly or wrongly, the economies of Emerging Europe have been more confident about financing investment with foreign funds.

These policies and behavioral patterns have implications for relative prices. Eastern European countries have been running their economies under higher pressure of demand. Their current account deficits are telling us that domestic absorption exceeds domestic production. This relatively high level of demand creates a tendency for real exchange rates to appreciate. In Emerging Asia, in contrast, absorption falls short of production, and the upward pressure on real rates is less. It is thus not surprising that discussion in Eastern Europe has centered on the question of whether real exchange rates are overvalued and current account deficits at current levels can be sustained, whereas in Emerging Asia the focus has been whether real exchange rates are undervalued and there are limits to reserve accumulation.

Emerging Asia has been able to limit the impact of capital inflows on domestic demand and real exchange rates through low-cost sterilization. Because interest rates in the region, notably in China, are low, it has been able to sell domestic-currency denominated government bonds and bills to mop up the monetary consequences of

\footnotetext{
${ }^{8}$ Another way of saying this is that they have been intent on accumulating large foreign reserves. This reaction is evident in the swing into current account surplus of Emerging Asia ex China starting in 1998. The fall in investment rates is particularly evident in the ASEAN 4, led by Indonesia.
} 
inflows without creating a burden for the fisc. ${ }^{9}$ This low level of interest rates reflects the relatively depressed investment demand of the post-crisis period and the special financial circumstances prevailing in China. In Emerging Europe, in contrast, interest rates are higher than in the advanced countries that are the source of the capital inflows (which is the circumstance more typical of emerging markets). This renders sterilization costly, forcing central banks and governments to allow financial inflows to feed through into domestic demand and real appreciation to a greater extent and to search for other expedients for coping with foreign capital.

This paper develops these themes and their implications, mainly for the accession economies, including Turkey, but also implicitly for Asia. Section 2 first considers the extent to which real exchange rates in Emerging Europe and Emerging Asia can be interpreted in terms of the factors enumerated above. We extend a framework due to Kim and Korhonen (2002) relating the real exchange rate to productivity trends, the shares of investment and government consumption in GDP, trade openness and - in our implementation - capital account openness. This allows us to attribute observed real exchange rates to Balassa-Samuelson effects, investment ratios, government spending ratios, and policies toward the external accounts.

Section 3 reviews the risks associated with large capital inflows and appreciating real exchange rates. We argue that these risks are at least as immediate for the economies of Emerging Europe as many other parts of the world - and more immediate than for the economies of Emerging Asia. This leads us in Section 4 to consider policies for managing capital movements and real exchange rates. The analysis there builds on

\footnotetext{
${ }^{9}$ Japan, one of the region's large accumulators of reserves, has not attempted to sterilize the impact on the domestic money supply of its large reserve accumulation, despite also possessing very low interest rates. But it, clearly, is a special case.
} 
evidence from a potential accession economy, Romania, that has already traveled a considerable way down the road that will eventually be followed by Turkey.

The basic message of this section is that although there exists a lengthy list of strategies that might be pursued in response to capital inflows, the only policy that is likely to be effective is fiscal consolidation. Unfortunately, there are political constraints to adjusting fiscal policy in response to the challenges of managing capital flows, although one can imagine some approaches to the design of fiscal mechanisms that might ameliorate this problem. This conclusion has implications for Emerging Asia as well: as financial conditions there, notably in China, continue to normalize, it will become more difficult for central banks and governments to sterilize inflows, creating the same challenges for fiscal policy.

Section 5 summarizes these points and reiterates their implications for current and future accession economies.

\section{Real Exchange Rates}

In this section we analyze the proximate determinants of real exchange rates in the accession economies. By now there is an immense literature on this subject (surveyed by Egert 2004). Our goal is not to add to the catalog of explanatory factors but to consider the extent to which the obvious policy and behavioral variables (investment ratios, government spending ratios, trade openness, capital account openness) can explain real exchange rate movements in Emerging Europe (and, by implication, the contrast with Emerging Asia). 
We adapt a framework due to Kim and Korhonen (2002) that permits a simple characterization of real exchange rates in the region. The model builds on the so-called Behavioral Real Exchange Rate literature (e.g. Clark and MacDonald 1998). In this literature the long-run real exchange rate is related to a set of observable behavioral variables, such relative per capita GDP (as a proxy for the Balassa-Samuelson effect), gross fixed investment as a share of GDP, government consumption as a share of GDP, and trade openness (exports plus imports as a share of GDP). In our implementation we also consider proxies for the volume of capital inflows. Variable definitions and sources are described in the appendix.

Panel unit root tests reject the null of stationarity, so the model is estimated in first differences. We treat the data as a panel, including country fixed effects. Like Kim and Korhonen, we also estimate the equation with lags of the independent variables, using the Akaike information criterion to choose the optimal number of lags. ${ }^{10}$ We start with the sample of small and middle-sized countries (both developed and developing) considered by Kim and Korhonen (KK). The advantage of this is that the typical country in the sample is not radically different in size from the typical accession economy; the corresponding problem is that the resulting sample is something of a hodge-podge. ${ }^{11}$

\footnotetext{
${ }^{10}$ We also experimented with the Pooled Mean Group estimator proposed by Pesaran et al. (1999), which allows for dynamics by introducing lags and allowing the coefficients to differ across countries in the short run while constraining them to equality in the long run. The joint Hausman test statistic constructed by Pesaran et al. confirms that we can constrain the long-run coefficients to be equal across countries. While the results using this more general specification are broadly consistent with those obtained using fixed effects where the coefficients are constrained to be equal across countries in the short run as well as the long run,they are sensitive to the composition of the sample. Dropping out an individual country can alter both the sign and significance levels of a number of the common long-run coefficients. We experimented as well with the Mean Group estimator that allows the coefficients to differ by country in both the short run and long run, but the large number of parameters estimated in this case meant that few coefficients were significantly different from zero.

${ }^{11}$ Kim and Korhonen's sample consists of Algeria, Chile, Colombia, Guatemala, Republic of Korea, Malaysia, Mexico, Morocco, Philippines, South Africa, Thailand, Turkey, Venezuela, Australia, Austria,
} 
However, our sample period is different: whereas Kim and Korhonen consider the period 1975-1999, our data continue through 2003. We define the real exchange rate as the product of the nominal exchange rate $E$ and the foreign price level $P^{*}$ divided by the domestic price level $P$. We use U.S. consumer prices as a proxy for $P^{*}$.

Taking the natural logarithm of $E P^{*} / P$ as the dependent variable, we obtain the results reported in the first column of Table 2 (including only the concurrent values of the independent variables) and Table 3 (including also lagged values). The results are consistent with those reported by Kim and Korhonen. Higher per capita incomes are associated with real appreciation, consistent with the operation of the Balassa Samuelson effect. ${ }^{12}$ Higher levels of fixed investment and government consumption are similarly associated with real appreciation; this makes sense insofar as higher levels of domestic demand tend to drive up the prices of domestic goods. The coefficient on trade openness does not have a consistent sign. In Table 2 a higher level of trade openness is associated with real depreciation, which is again intuitive, since a lower real exchange rate is necessary to encourage foreign demand for domestic goods (to ensure adequate domestic consumption). In Table 3 the estimated effect of trade openness is negative.

We then re-estimated the relationship on data for a sample of emerging markets. We chose middle-income countries largely in East Asia and Latin America most comparable to Emerging Europe. ${ }^{13}$ (We refer to this as the Eichengreen-Choudhry or EC

Belgium, Canada, Cyprus, France, Greece, Hong Kong, Iceland, Ireland, Italy, Japan, Norway, Portugal, Sweden, and Switzerland.

${ }^{12}$ Note that since we are including country fixed effects, we are picking up here the impact of secular income growth on changes in real exchange rates over time, not of cross-country variations in incomes and productivity.

${ }^{13}$ The countries in our sample are Argentina, Bolivia, Brazil, Chile, China, Colombia, Costa Rica, Dominica, Dominican Republic, Ecuador, El Salvador, Guatemala, Guyana, Honduras, Indonesia, Israel, Republic of Korea, Malaysia, Mexico, Nicaragua, Panama, Papua New Guinea, Paraguay, Peru, Philippines, Singapore, Thailand, Trinidad and Tobago, Turkey, Uruguay, and Venezuela. Note that the 
sample.) The results in column 2 are broadly similar to before, the main difference being that our crude proxy for the Balassa-Samuelson effect no longer enters with a coefficient that differs significantly from zero at standard confidence levels when only the contemporaneous value is included, as in Table $2 .^{14}$

Next we added capital inflows, measured as the net sum of the balance of direct investment, portfolio investment, and other investment transactions as a share of GDP, in order to capture their impact on the real exchange rate. In column 3 this variable enters with a negative sign, confirming that inflows lead to real appreciation. ${ }^{15}$ A potential problem is simultaneity: real exchange rate movements affect capital inflows as well as the other way around. We therefore instrumented the capital inflows variable using measures of the age structure of the population (following Eichengreen and Fifer 2002) and the quality of institutions (following Kalemi-Ozcan, Alfaro and Volosovych 2004). Our instruments are the percent of the population between 15 and 64, the ratio of dependents to working-age population, percent of the population in urban areas, Freedom House's two yearly scores of economic freedom and strength of property rights, Polity scores of the strength of political institutions, and year and country fixed effects. The estimated effect of capital inflows, reported in the fourth column, is robust to this econometric treatment. ${ }^{16}$

accession economies are themselves omitted from this sample, given the problems for estimation created by rapid structural change over the sample period. Thus, the forecasts of real exchange rates for the accession economies we provide below can be regarded as out-of-sample forecasts

${ }^{14}$ Fixing this would presumably require constructing a measure of productivity growth that distinguished traded and nontraded goods sectors.

${ }^{15}$ The other effects are basically unchanged.

${ }^{16}$ The point estimate in Table 2 may be implausibly large: it suggests that a capital inflow in the amount of 4 per cent of GDP leads to a 12 per cent real appreciation, other things equal. That in Table 3 suggests instead an effect an order of magnitude smaller. 
We now use the coefficient estimates in column 3 of Table 2 and the values of the independent variables to compare actual exchange rates with their predicted levels. We show three series in Figures 1-11. The line interrupted by diamonds is the actual real exchange rate. (Recall that, as defined, a decline denotes a real appreciation.) The dark line is the level of the real exchange rate predicted by country-specific values of the independent variables. Finally, the light line is the value of the real exchange rate predicted by sample mean values of the independent variables for each year. The Czech Republic, Hungary, Slovakia and, to a lesser extent, Slovenia appear at least modestly overvalued. Poland appears to be fairly valued on the basis of our estimates. Turkey appears to have gained some relief from a modest overvaluation as a result of its 2001 devaluation, but that problem seems to have reemerged subsequently as a result of its relatively high inflation and relatively strong nominal rate. ${ }^{17}$

In contrast, most of the East Asian countries appear at least modestly undervalued in the post-financial-crisis period, the devaluations of 1997-8 having led to large real depreciations and subsequent policies having kept their currencies competitively valued. Note, however, that Thailand is not obviously undervalued relative to the levels warranted by the country-specific values of the independent variables. And, by this measure, there is little evidence that China is significantly undervalued. ${ }^{18}$

\footnotetext{
${ }^{17}$ That the predicted value of the real rate to depreciates over time in most of these countries is counterintuitive, given the tendency toward real appreciation generally evident in transition economies. Here it reflects the strong estimated effect of greater trade openness (which leads to real depreciation, other things equal) in combination with the weak estimated effect of real GDP (the absence of a strong estimated Balassa-Samuelson effect working in the other direction). Thus, we would not make too much of the predictions generated by these equations, except insofar as they confirm the tendency for capital inflows to cause real appreciation.

${ }^{18}$ The progressively greater openness of the Chinese economy translates into real depreciation according to our estimates. This is offset by growing capital inflows and a rising investment rate, both of which make for real appreciation. Be this as it may, this controversial finding clearly warrants further analysis.
} 
The particularities of these country-specific results notwithstanding, our results broadly confirm that the Eastern European and East Asian countries have managed capital inflows in ways with very different implications for the evolution of real exchange rates. Although capital inflows have important implications for the evolution of exchange rates, differences in their magnitude - and differences in the other determinants of real exchange rates analyzed in Table 2 - cannot by themselves explain observed differences in real exchange rate outcomes. In addition there is evidently a role for the management of capital inflows of the sort pointed to in the introduction of this paper.

\section{Real Exchange Rate Risks}

The risk of allowing a current account deficit to develop and the real exchange rate to appreciate substantially in response to capital inflows is that those inflows can dry up abruptly, requiring sudden compression of the balance and a sharp shift in the real exchange rate. As observers familiar with the experience of Emerging Asia will know, "sharp compression of the balance" is an antiseptic phrase that disguises the painful nature of the fall in spending necessary for narrowing a current account deficit. In practical terms, the adjustment works as follows. As foreign capital stops flowing in, financial conditions tighten. The trigger has often been a rise in U.S. interest rates, as higher yields make investing in the safe haven of U.S. Treasury bonds more attractive. This possibility has been much discussed, of course, since the Fed issued a strong statement of concern about inflation in mid-March. But one can equally imagine other factors such as political uncertainty in the capital-importing country, capable of triggering a similar reaction. The resulting rise in interest rates facilitates adjustment to the 
declining availability of financial resources by reducing spending in general and investment spending in particular. As absorption falls, resources are redeployed to the export sector. This reallocation is facilitated by a rise in the relative price of exports (depreciation of the real exchange rate), which is in turn achieved through a combination of lower domestic inflation and, more likely, a higher rate of currency depreciation.

In the industrial countries this adjustment has sometimes been completed without severe disruptions. The decline in the exchange rate is orderly. Exports are crowded in. The fall in the rate of growth is moderate. ${ }^{19}$ In emerging markets, in contrast, the adjustment associated with sudden stops has frequently been disruptive. ${ }^{20}$ Typically the size of the capital account reversal and therefore the requisite change in domestic spending have been larger, requiring still larger changes in the relative price of traded goods. In addition, the financial system is more susceptible to destabilization by these events. The exchange rate depreciation brought on by the sudden stop has caused financial distress for banks and nonfinancial firms with currency mismatches on their balance sheets. The result has been a sharp fall in output, major declines in asset prices, and a surge in bankruptcies. This is a simple way of characterizing what happened in Emerging Asia in 1997-8. The question is whether something similar could happen in Emerging Europe.

A number of reasons are given for why policy makers in Emerging Europe can afford to be more sanguine. The Czech Republic, Slovakia, Slovenia, Hungary, Poland and the Baltics already possess the safety net of EU membership. Eventually - in most

\footnotetext{
${ }^{19}$ See Croke, Kamin and Leduc (2005) for a study that reaches these conclusions but also Edwards (2005) for a dissenting view where it is argued that even in the industrial countries the output effects are more likely to be negative.

${ }^{20}$ Often but not always: see Milesi-Ferretti and Razin (1997) and Edwards (2004).
} 
cases presumably by the end of the decade - they will also adopt the euro. The main advantage of EU membership in this context is that it minimizes the risk of destabilizing shifts in government policy that might precipitate a sudden reversal in the direction of flows. Both the strictures of the acquis communautaire and the widening web of commitments to their EU partners minimize the risk that some future populist government will nationalize foreign-owned enterprises or otherwise expropriate foreign investments. Unfortunately, they do not also rule out the possibility that new doubts about fiscal sustainability or a major bank failure could precipitate the reversal of capital flows, especially in the period prior to adoption of the euro. In a period when the new member states are supposed to be demonstrating their readiness for adopting the euro, it seems unlikely that the incumbents will bail them out of their difficulties.

To be sure, once these countries are allowed to adopt the euro, one channel through which the destabilizing effects of such reversals are felt - the interaction of exchange rate depreciation with currency mismatches - will be eliminated. Since these countries will be borrowing mainly within the euro area, there will be neither exchange rate movements nor currency mismatches to exert destabilizing balance-sheet effects. The only problem is that the EU seems intent on consigning the new members (most of them at least) to an extended waiting period in the euro area's anteroom. All estimates of the dates by which the new members will be permitted to adopt the euro seem to be undergoing revision in the same direction, namely that of later adoption. In any case, just eliminating currency mismatches will not eliminate the other sources of financial fragility that may still cause capital flows to reverse abruptly. 
Two other observations commonly offered to provide reassurance regarding Emerging Europe's position are that its current account deficits reflect imports of capital goods and intermediate inputs required for the production of exports, and that its deficits are being fully financed by FDI inflows. ${ }^{21}$ That imports have a high capital-goods and intermediate-input component is perhaps more reassuring than the alternative. ${ }^{22}$ But the argument that imports of investment goods are not a problem (and its cousin, the argument that current account deficits reflecting high investment are benign) has been discredited by the Asian crisis. High investment is not the same as efficient investment, and inefficient investment is unlikely to deliver a significant increase in exports. Even if funds are allocated efficiently, there is still certain to be a considerable delay between the importation of capital goods and the subsequent increase in exports during which any number of things can go wrong.

Some economists (e.g. Taylor and Sarno 1999) suggest that FDI is more stable than portfolio capital flows - that the permanent component of FDI is larger. ${ }^{23}$ But if a shock causes FDI to fall off abruptly, the result can still be a sharp shift in the real exchange rate to which banks and firms find it painful to adjust. The saving grace, it is said, is that FDI is unlikely to reverse direction and flow out in large amounts. Foreign capital equipment, once installed, is effectively bolted to the floor. The limitation of this view is that foreign-owned enterprises also hold local financial assets that they can and will sell if things go wrong, resulting in large outflows and an even larger shift in the real exchange rate.

\footnotetext{
${ }^{21}$ Not in all cases, however; in Hungary, for example, FDI inflows cover only about half of the current account deficit. The remainder is largely accounted for by portfolio capital flows, heavily in the form of nonresident purchases of government bonds.

${ }^{22}$ In Turkey capital and intermediate goods account for more than 80 per cent of total imports.

${ }^{23}$ Although not all studies reach the same conclusion.
} 
All these are reasons to worry that the risks posed by large current account deficits and appreciated real exchange rates are no less in Emerging Europe than other regions. The question is then what governments and central banks should do when faced with a surge of capital inflows.

\section{Strategies and Tactics}

What is the standard advice for dealing with these risks? The standard menu includes seven items: increasing exchange rate flexibility, maintaining capital account restrictions, strengthening prudential supervision, sterilizing inflows, loosening monetary policy, tightening fiscal policy, and negotiating a program with the IMF. The economies of Emerging Europe have experimented with most of these strategies. However, all but one of them have serious limitations. In practice most of the burden falls on tightening fiscal policy. And this is problematic since there are political constraints on fiscal adjustment.

In what follows we illustrate these points with evidence from the experience of Romania. We focus on this case because Romania is at the stage of the accession process that Turkey is likely to enter, say, five years from now, and also because Romania has attempted to deploy the entire range of policies commonly recommended for managing capital inflows. Romania is currently scheduled to join the EU in 2007, although the safeguard clause could conceivably be invoked, pushing back accession to 2008. The country is running a substantial current account deficit on the order of 7.5 per cent of GDP, although most of this is being financed by FDI, given Romania's attractiveness as one of the next wave of accession economies and restrictions on other forms of foreign 
investment. According to the agreement negotiated with the EU, all restrictions on financial flows will have to be eliminated by 2007 at the latest. In fact, the government is moving even faster. It allowed nonresidents to start opening leu-denominated deposit accounts on April $11^{\text {th }}$, and at last report it is planning to substantially open the capital account by the end of this June. ${ }^{24}$

The danger is that the country will then be identified as the next convergence play if it hasn't been already. ${ }^{25}$ Large amounts of portfolio capital could flow in, creating inflationary pressures and leading to real appreciation in the short run and the risk of a disruptive reversal subsequently. The IMF worries that real appreciation could erode the competitiveness of the textile and furniture sectors into which much of the FDI inflow is currently going, causing this relatively stable source of financing to dry up. If doubts then develop about the sustainability of the current account, the inevitability of convergence could be called into question, and financial capital flows might reverse direction, with devastating consequences.

Standard advice for discouraging hot-money inflows is to introduce greater exchange rate uncertainty (Goldstein 2002). In the presence of two-way bets, speculators are less likely to take large unhedged bets on trend appreciation. In late 2004 the National Bank of Romania therefore announced that it intended to limit foreign exchange market intervention and stop announcing indicative real appreciation targets for the leu. Both measures are designed to render the path of the exchange rate less predictable. ${ }^{26}$

\footnotetext{
${ }^{24}$ As an early step in that direction, it allowed non-residents to open leu-denomination accounts beginning in June.

${ }^{25}$ For evidence of this see Deutsche Bank (2005a).

${ }^{26}$ They are also seen as preconditions for the central bank's eventual move to inflation targeting, an exchange-rate centered policy strategy being seen as incompatible with this approach to monetary management.
} 
The effectiveness of this measure can be questioned, however, since there has been only a limited increase in currency volatility. ${ }^{27}$ Expectations of secular appreciation remain strong, forcing the NBR to lean against the wind, damping volatility. In addition, once Romania actually enters the EU, it will come under pressure to enter the Exchange Rate Mechanism of the European Monetary System, whose bands will further limit the scope for exchange rate variability and the central bank's ability to introduce a modicum of exchange rate uncertainty.

The Romanian National Bank is reportedly considering a package of measures to limit short-term inflows, including a minimum reserve requirement on financial investment by non-residents and/or a tax on investments under one year (Deutsche Bank 2005b). ${ }^{28}$ The experience of other countries, Chile for example, suggests that such measures can help to limit the volume of portfolio capital inflows or at least lengthen their average maturity. In addition the evidence suggests that the effectiveness of such restrictions tends to decline over time, as market participants find a growing number of ways of circumventing them. The fact that Romania has closed the chapter of the acquis concerned with the free movement of capital suggests in any case that these measures have to be regarded as temporary, since Brussels is unlikely to permit their retention once the country joins the EU. Whether it will object to them even before membership is an accomplished fact remains unclear. One hopes not, for such measures can play a useful role in limiting the extent of maturity mismatches.

\footnotetext{
${ }^{27}$ The date of the NBR's announcement was 2 November 2004. Before this time, the standard deviation of daily changes in the leu was about 180 leu per dollar. After the announcement, the standard deviation as of mid-April increased to 430 leu per dollar. The standard deviation of the daily percentage changes was .5\% before the announcement, and $1.5 \%$ afterwards.

${ }^{28}$ In part this is an effort to respond to the growing ability of investors to get around more selective regulations through, inter alia, the use of special-purpose vehicles.
} 
This way of framing the regulation of short-term capital inflows encourages one to think of such measures as prudential policy. In turn, this suggests buttressing these transitory measures with permanent prudential regulations. Strengthening the prudential supervision of the banks is a way of reducing the risks to the financial system from large capital inflows and the possibility of their reversal. ${ }^{29}$ Raising capital and liquidity requirements above internationally mandated minimum standards and limiting permissible currency mismatches are the standard recommendations in this connection. ${ }^{30}$ At the same time, the case of Argentina where exceptionally ambitious capital and liquidity requirements were in fact adopted suggests that these policies have limits; the banks will still suffer severely if the firms and households to which they have passed on that currency exposure find themselves unable to repay when capital flows reverse direction and the currency depreciates. In the corporate sector, excessive dependence on foreign-currency funding can be discouraged by strengthening corporate governance (requiring firms to disclose more financial information and strengthening the legal rights of outside shareholders). Unfortunately, such fundamental institutional reforms are difficult for emerging markets; even under the best of circumstances they take time to complete.

The other obvious way of attempting to neutralize the impact of imported capital on real and financial conditions is by sterilizing inflows. The central bank sells domesticcurrency denominated bonds in exchange for the foreign-currency finance that has

\footnotetext{
${ }^{29}$ The greater internationalization of their banking systems may be an area where Emerging Europe has an advantage over Emerging Asia, insofar as the foreign banks that have penetrated the region have tighter internal controls and tighter prudential standards. To be sure, the extent of banking-system internationalization varies considerably within the region (see Valintinyi 2003). This is an area where Turkey, for example, can go considerably further.

${ }^{30}$ See e.g. Goldstein and Turner (2004).
} 
flowed in, mopping up the additional liquidity and adding foreign bonds to its asset portfolio. The problem for a country like Romania is that sterilization is costly: the interest rates on the additional domestic-currency-denominated bonds that the authorities must now service exceeds the yield on the foreign bonds that they add to their portfolio. Injecting additional domestic-currency-denominated bonds into the market drives up interest rates, which further increases the costs of sterilization, while at the same time heightening the incentive for foreign investors to shift more financial capital toward the country. This makes large-scale sterilization costly for the fisc and potentially problematic.

In contrast, many Asian countries, enjoying low interest rates, have not encountered this problem when sterilizing inflows, at least yet. In China, for example, sterilization is economical because the interest rate on domestic government securities remains less than that on U.S. Treasury bonds. Over time, however, Chinese interest rates will rise, rendering this strategy more problematic.

Another alternative sometimes recommended for dealing with capital inflows is to cut interest rates. Lower rates will moderate the inflow-induced appreciation of the currency, limiting the erosion of competitiveness, and make interest arbitrage less attractive. This strategy avoids the problems with sterilization reviewed in the previous paragraph. Thus, the first half of March saw a number of Central and Eastern European central banks cut interest rates with this goal in mind. But cutting interest rates when inflation and demand are accelerating is perverse and potentially damaging to credibility. It is undesirable to the extent that it simply substitutes one source of excess liquidity and inflationary pressure for another. Insofar as the cut in interest rates is inappropriate given 
domestic conditions, expectations will develop that it will probably be reversed anyway, minimizing its impact. ${ }^{31}$

This leaves fiscal policy. Consolidated budget deficits in the four big Central and Eastern European countries are averaging about 4 per cent of GDP. In Romania the deficit is 2 per cent. In Turkey it is 6 per cent. ${ }^{32}$ In all these countries experiencing capital inflows there is room for fiscal tightening. Tightening fiscal policy will offset some of the expansionary impact of capital inflows on domestic demand, thereby limiting inflation and real appreciation. It will put downward pressure on interest rates, limiting the incentive for capital inflows.

For Romania the IMF has therefore recommended cuts in public spending and/or increases in taxes. The difficulty is that its call comes in the wake of an electoral campaign in which the victorious party promised tax reductions. It flies in the face of the additional fiscal costs of readying the country for EU membership. Romania will receive transfers from the EU for public investment in the amount of 4 per cent of GDP over the next 3 to 4 years, and these require domestic co-financing through the budget. Pension reform in preparation for EU membership will also have substantial short-run fiscal costs. ${ }^{33}$ In the hope of remaining an attractive destination for FDI, Romania has matched Slovakia's move to a flat 16 per cent tax (replacing a corporate profits tax of 25 per cent and personal income taxes ranging from 18 to 40 per cent); this too is likely to have some

\footnotetext{
${ }^{31}$ A related strategy is to intervene in the foreign exchange market to limit the currency's appreciation (as for example Slovakia did starting in March). But this approach is limited by the costs of sterilization and by the incompatibility of the measure with the desire to introduce greater exchange rate uncertainty (see above).

${ }^{32}$ As estimated by Morgan Stanley for 2005.

${ }^{33}$ As recognized in the recent revision of the Stability and Growth Pact.
} 
short-run revenue cost. The IMF recommends an offsetting increase in VAT tax rates (to 21 per cent), the problem being that this would be highly visible to consumers.

Not infrequently one observes reluctance on the part of the authorities to pursue fiscal consolidation. This is not surprising when one recalls that the measures in question operate by increasing the cost of funding to the private sector and reducing effective demand and growth. Fiscal consolidation will tend to reduce demand and growth assuming that the standard Keynesian effects dominate. This means that growth will decelerate in the short run, other things equal. ${ }^{34}$ The argument for nonetheless pursuing these measures is that growth at this now slightly slower rate is more likely to be sustainable. It is less vulnerable to sudden interruption by the disruptive reversal of capital flows. Unfortunately, in new democracies it is often difficult for governments to incur these short-term costs in return for long-term benefits.

The same difficulty also arises for the other measures recommended for managing capital inflows. Requiring banks to hold more liquid balances or preventing them from funding themselves in foreign currency when they lack foreign-currency-denominated assets increases lending and borrowing costs. A higher cost of capital slows investment and growth. Lower investment and growth are precisely what strengthen the current account. They are what produce a balance of payments equilibrium consistent with the now lower level of portfolio capital inflows. But they are not easy for governments to justify and defend in the face of electoral pressure.

\footnotetext{
${ }^{34}$ Non-Keynesian effects may be felt in circumstances where the public debt is clearly on an unsustainable path, in which case early fiscal consolidation may in fact inspire confidence and therefore prove expansionary. But when the fiscal consolidation is temporary rather than permanent and undertaken for other reasons, such as to limit the inflationary effects of capital inflows, this case is more difficult to make.
} 
An IMF program is often recommended as a way of coping with these difficulties. Romania (like Turkey) has a program that requires the government to commit to specific fiscal actions. Fiscal consolidation may be easier for the government to sell to the public when the authorities can point to the availability of IMF resources as one of the benefits. In addition investor confidence may be strengthened by the presence of a Fund program, rendering a country less susceptible to sudden capital flow reversals. Unfortunately, the record of compliance of program countries with the Fund's fiscal conditions is at best checkered. ${ }^{35}$ We are unaware of research showing that program countries are less susceptible to sudden stops. ${ }^{36}$ The financial insurance provided by a Fund program is very limited compared to the size of the potential reversal, while changes in disbursals are unlikely to occur at the same speed as changes in capital flows.

At the time of writing, we see these problems visibly in Hungary. The Hungarian government is running budget deficits on the order of 4 per cent of GDP ( 5 per cent if payments associated with reform of the pension system are included). This combines with large capital inflows to create strong demand pressure, which is pushing up the real exchange rate and fueling a current account deficit currently running at 8 per cent of GDP. The removal of restrictions on capital flows, as required by the country's accession to the EU, has enabled financial institutions to fund themselves abroad, in foreign currency, and make euro- and Swiss-franc-denominated loans to households and firms. (60 per cent of new mortgages are now foreign-currency denominated. Mortgage loans and consumer loans, notably for financing purchases of motor vehicles, were the best

\footnotetext{
${ }^{35}$ See Schadler, Bennett and Carsovik (1995) for an early review of the literature and Dreher and Vaubel (2003) for a more recent analysis.

${ }^{36}$ Studies of this question would have to confront the intrinsic difficulty of identifying the effects of IMF programs that bedevil previous such analyses. Among other things, they would have to address the very non-random assignment of IMF programs.
} 
selling bank products in $2004{ }^{37}$ ) The result is created growing currency mismatches threatening to create serious financial problems and the collapse of consumer confidence if and when a shock to confidence causes the exchange rate to weaken.

The obvious treatment is to reduce the budget deficit and thereby moderate demand pressure, limit the appreciation of the real exchange rate, lower domestic interest rates, and stem capital inflows. Unfortunately, in a new democracy all this is easier said than done. The Hungarian government has a history of setting ambitious fiscal targets and missing them. Whether it does better this time may turn out to be critical for financial stability.

\section{Conclusion}

This paper has considered the challenges of managing capital flows in Emerging European countries aspiring to membership in the European Union. It has shown that policies leading to dependence on capital inflows can have important implications for relative prices and macroeconomic conditions. For a variety of reasons the countries of Emerging Europe have run larger current account deficits and relied on foreign finance for a larger share of their investment than the economies of Emerging Asia. This explains, at least in part, the different evolution of their real exchange rates. It also renders them more vulnerable to real and financial disruptions if capital inflows are interrupted.

We then considered a variety of policies that have been suggested for addressing these problems: increasing exchange rate flexibility, maintaining capital account restrictions, strengthening prudential supervision, attempting to sterilize inflows,

${ }^{37}$ See Barcza (2005). 
loosening monetary policy, tightening fiscal policy, and negotiating a program with the IMF. The experiences and arguments here suggest that only fiscal policy adjustments are likely to contribute significantly to a solution. The other strategies tend to have either a marginal impact or counterproductive side-effects. Although Asia has had an easy way out of this dilemma as a result of special financial circumstances causing interest rates in the region to be even lower than those prevailing in the rest of the world, this is not likely to remain the case indefinitely. Sooner or later, the burden on and need for adjustments in fiscal policy will become greater.

These dilemmas are already evident in Turkey, which has adopted most of the standard treatments for coping with large capital inflows. The country has already moved to a managed float: central bank intervention in the foreign exchange market is limited to preventing excessive volatility without attempting to target a trend level. ${ }^{38}$ Subject to these constraints it has sought to sterilize inflows, purchasing foreign exchange through market-friendly auctions. It has negotiated a new three-year program with the IMF. It has strengthened supervision and regulation of the banking and financial system. It has tightened fiscal policy, aiming for a primary surplus of at least 6.5 per cent of GDP. The modest impact of these measures on the volume of capital inflows is a visible demonstration of the limited efficacy of the standard measures.

What more, then, can the authorities do? Clearly, there are political limits to further adjusting fiscal policy in a new democracy. One additional measure that the Turkish authorities might contemplate is imposing holding-period taxes and/or deposit requirements on portfolio capital inflows in an effort to skew these in the direction of

\footnotetext{
${ }^{38}$ It plans to move to an explicit inflation targeting strategy in 2006, at which point a still greater degree of exchange rate volatility will presumably be permitted.
} 
longer maturities, like the taxes and deposit requirements used for a time by Chile and currently under consideration by Romania. Another is to redesign the country's designing fiscal institutions so that they do some of the necessary adjustment automatically. A fiscal system that taxes nontraded goods as extensively as traded goods will raise additional revenues when capital inflows cause the real exchange rate to appreciate and shift additional resources into the nontradables sector. Recent efforts at tax simplication, by seeking to bring the underground economy to the surface, may have some effect in these terms. Special taxes on real estate transactions may provide automatic stabilization, given that the property market tends to be disproportionately stimulated by capital inflows. ${ }^{39}$

Unfortunately, none of this guarantees the country insulation from the ebb and flow of international capital movements. Such is the unavoidable fate of a country committed to globalization and to accession to the European Union.

\footnotetext{
${ }^{39}$ On the other hand, the kind of flat taxes that are increasingly popular in the region may be counterproductive from this point of view since they make it less likely that the increased incomes and activity produced by capital inflows will push taxpayers into higher brackets.
} 
Table 1. External Financing (billions of dollars)

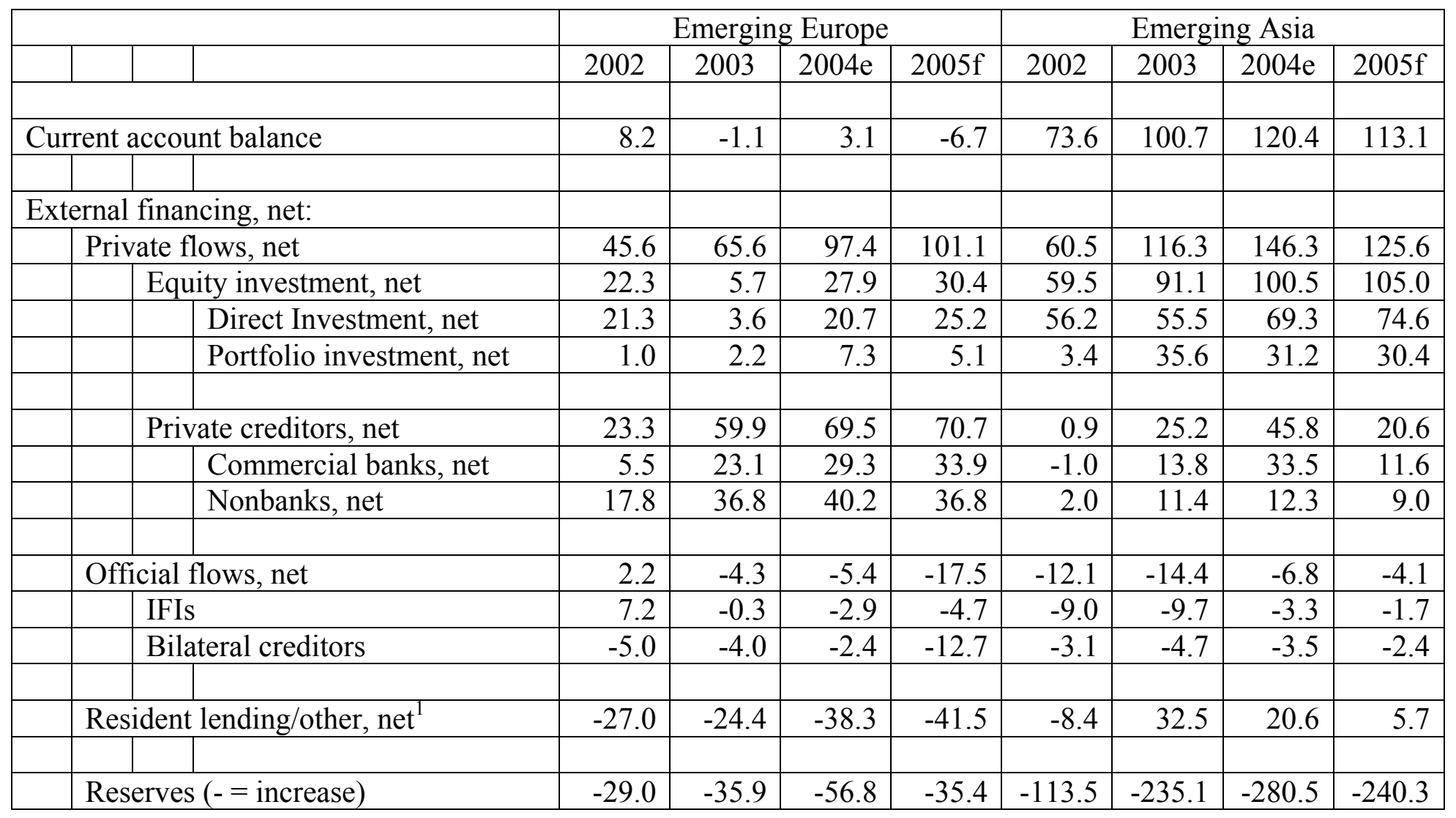

Notes: $\mathrm{e}=$ estimate, $\mathrm{f}=\mathrm{IIF}$ forecast, ${ }^{1}$ Including net lending, monetary gold and errors and omissions.

Source: Institute of International Finance (2005). 
Table 2: Fixed-Effects Estimates of Determinants of Real Exchange Rates

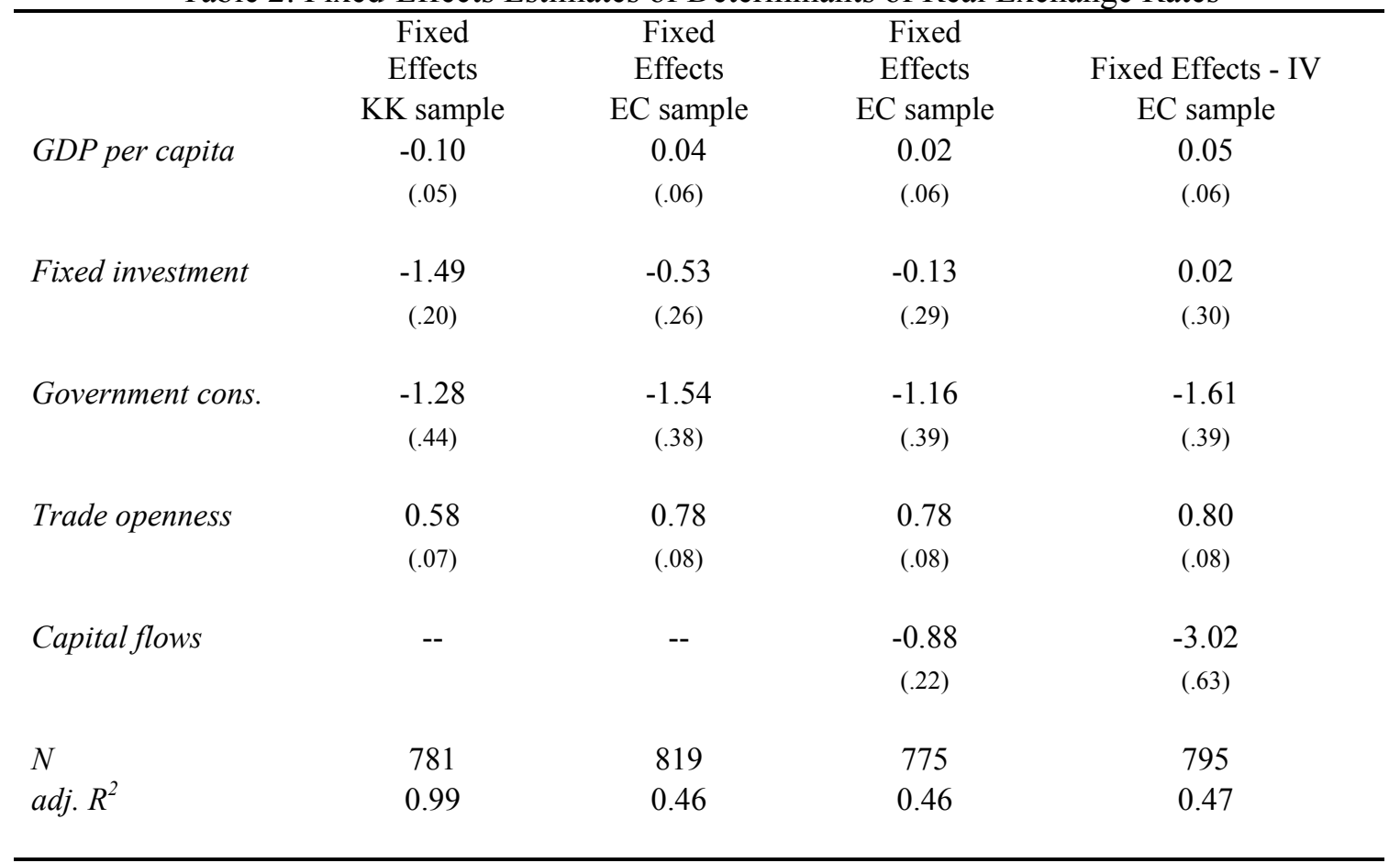

Notes: Standard errors appear in parantheses.

KK denotes Kim-Korhanen sample.

$\mathrm{BC}$ denotes Eichengreen-Choudhry sample

Source: see text. 
Table 3: Fixed-Effects Estimates of Determinants of Real Exchange Rates, with Lags

\begin{tabular}{lcccc}
\hline & Static FE & Static FE & Static FE & Static FE - IV \\
& KK sample & EC sample & EC sample & EC sample \\
GDP per capita & -0.46 & -0.72 & -0.58 & -0.65 \\
& $(.03)$ & $(.03)$ & $(.03)$ & $(.03)$ \\
Fixed investment & & & & \\
& -0.70 & -0.72 & -0.65 & -0.65 \\
Government cons. & $(.04)$ & $(.04)$ & $(.03)$ & $(.03)$ \\
& -0.49 & -0.60 & -0.53 & -0.53 \\
Trade openness & $(.04)$ & $(.03)$ & $(.04)$ & $(.03)$ \\
& -0.39 & -0.26 & -0.50 & -0.45 \\
Capital flows & $(.04)$ & $(.04)$ & $(.03)$ & $(.04)$ \\
& & & & -0.30 \\
$N$ & -- & -- & -0.45 & $(.03)$ \\
adj. $R^{2}$ & & & $(.03)$ & 868 \\
& 812 & 868 & 868 & 0.44 \\
\hline
\end{tabular}

Notes: Standard errors appear in parantheses.

KK denotes Kim-Korhanen sample.

$\mathrm{BC}$ denotes Eichengreen-Choudhry sample

Source: see text. 
Figure 1. Real Exchange Rates for the Czech Republic

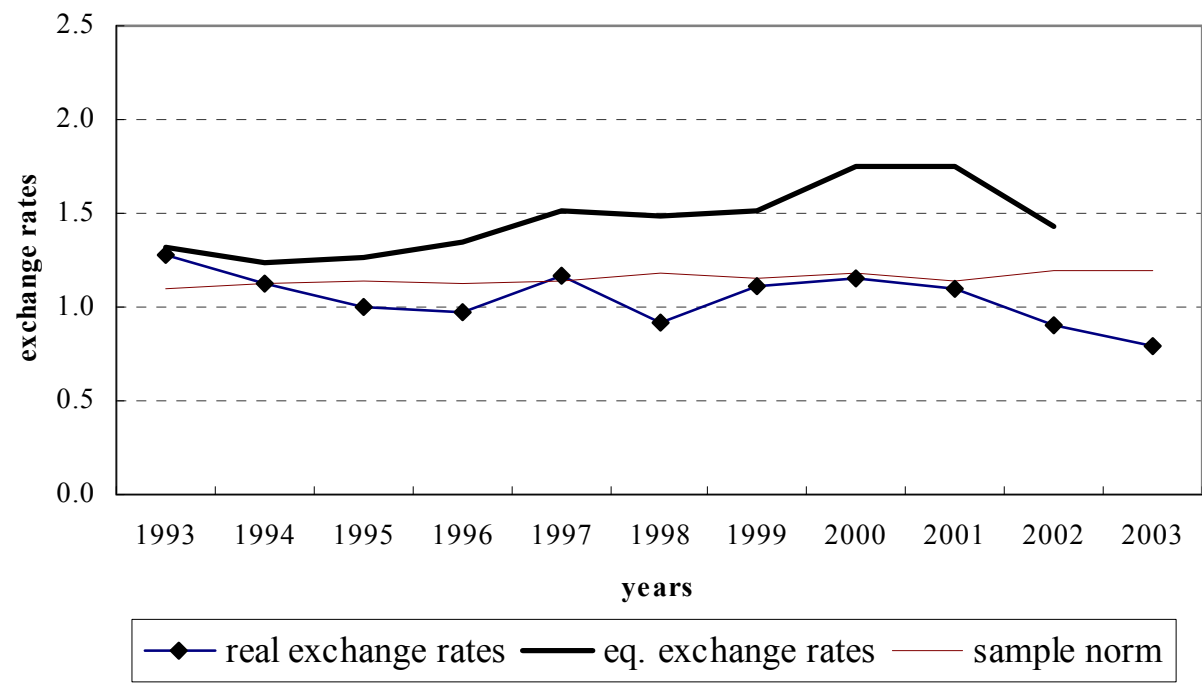

Figure 2. Real Exchange Rates for Hungary

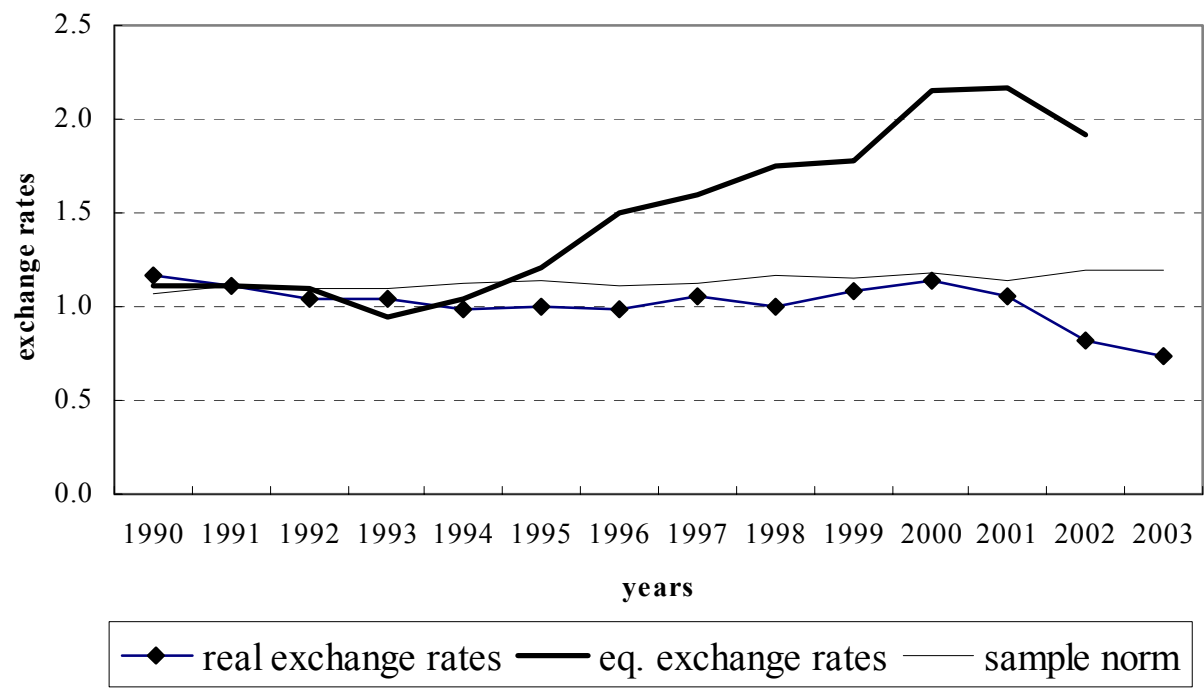


Figure 3. Real Exchange Rates for Poland

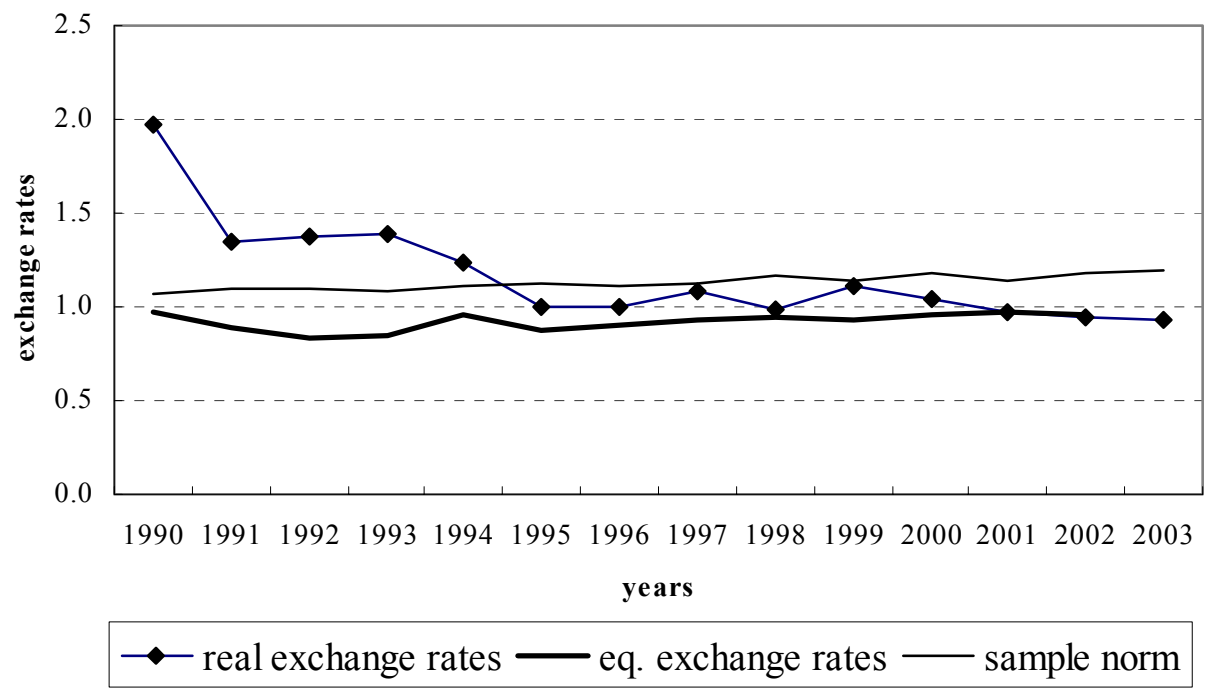

Figure 4. Real Exchange Rates for Slovakia

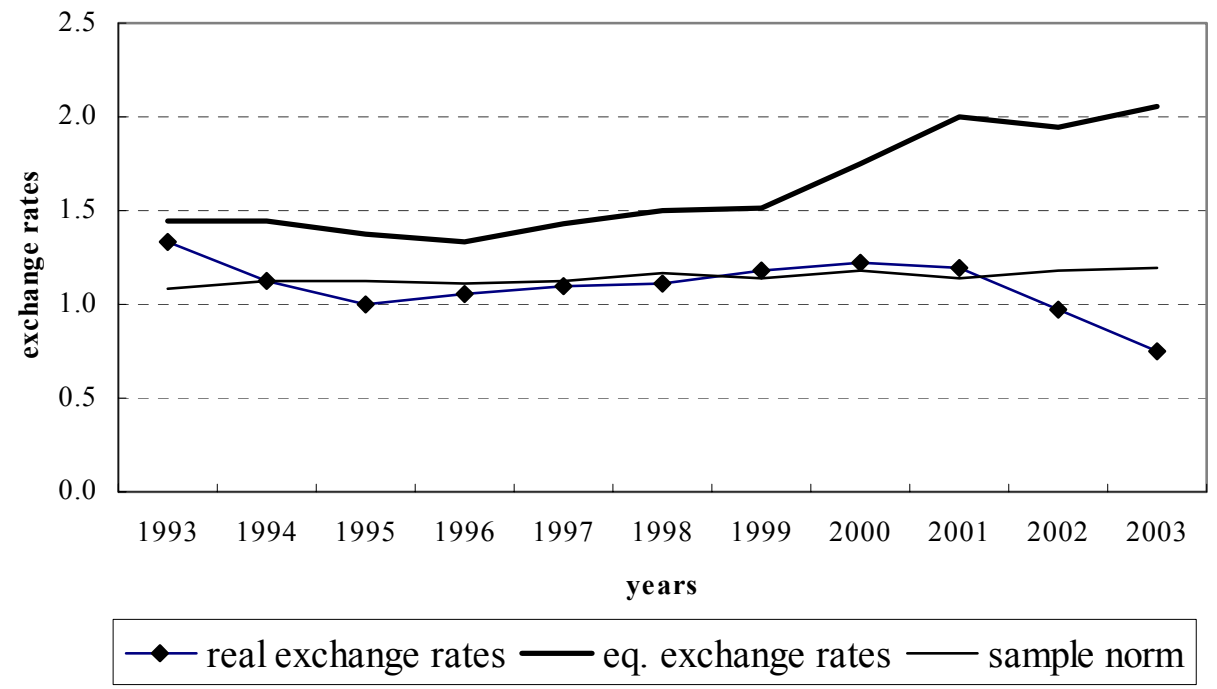


Figure 5. Real Exchange Rates for Slovenia

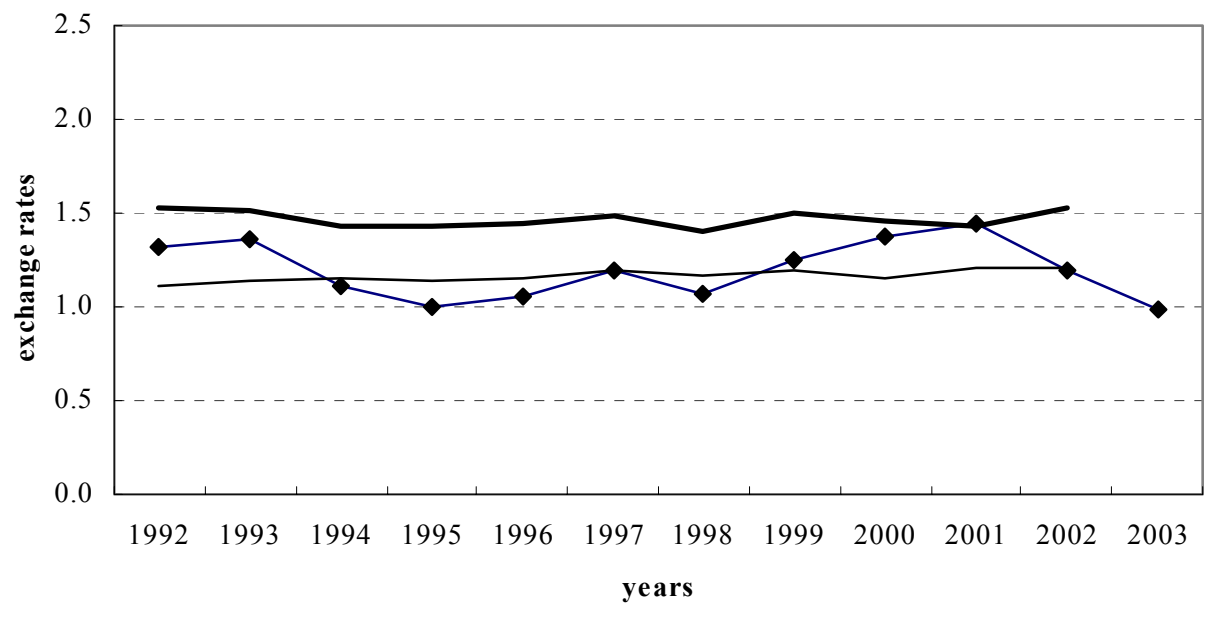

- - real exchange rates - eq. exchange rates - sample norm

Figure 6. Real Exchange Rates for Turkey

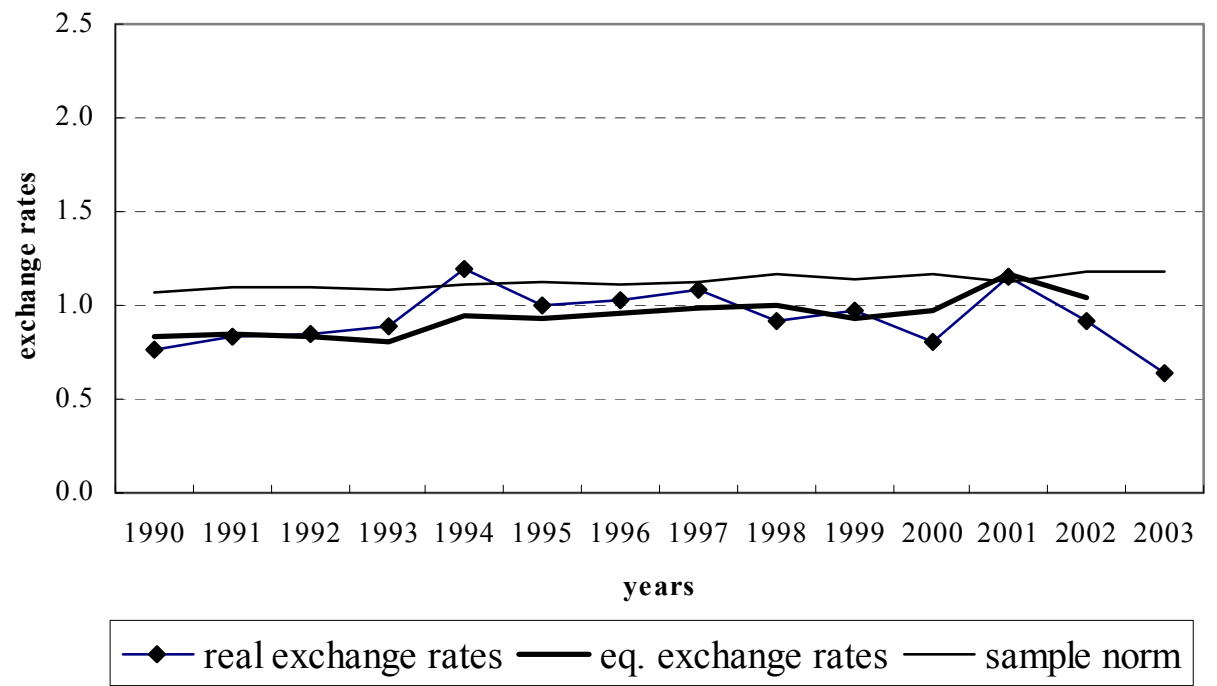


Figure 7. Real Exchange Rates for China

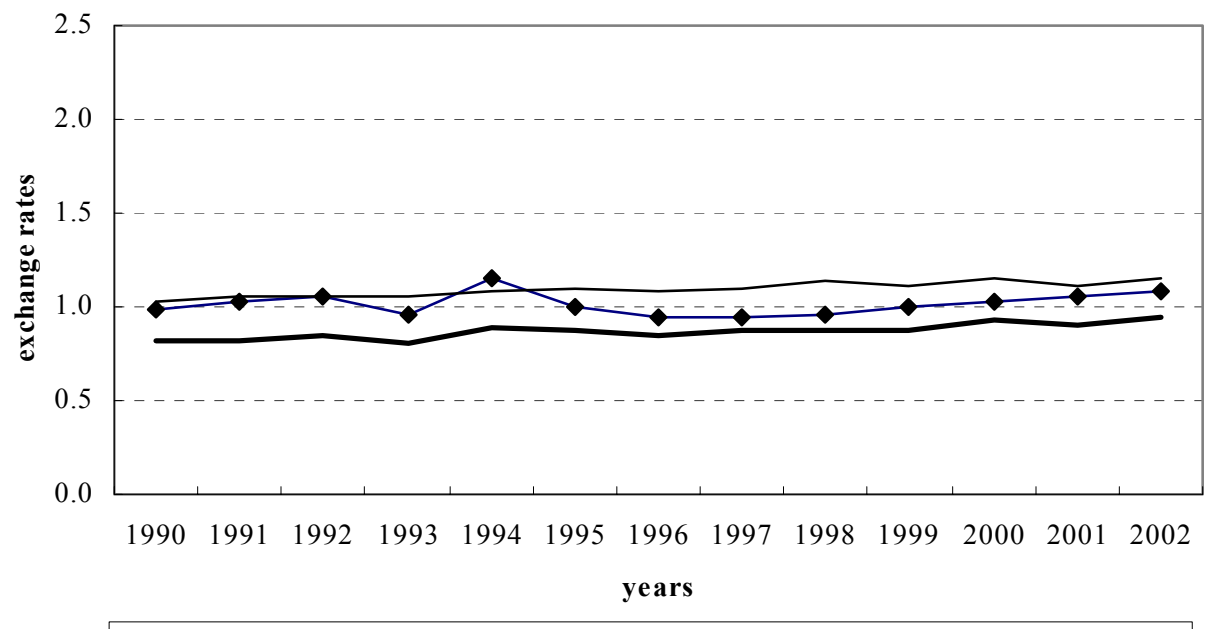

$\multimap$ real exchange rates $\longrightarrow$ eq. exchange rates $\_$sample norm

Figure 8. Real Exchange Rates for Indonesia

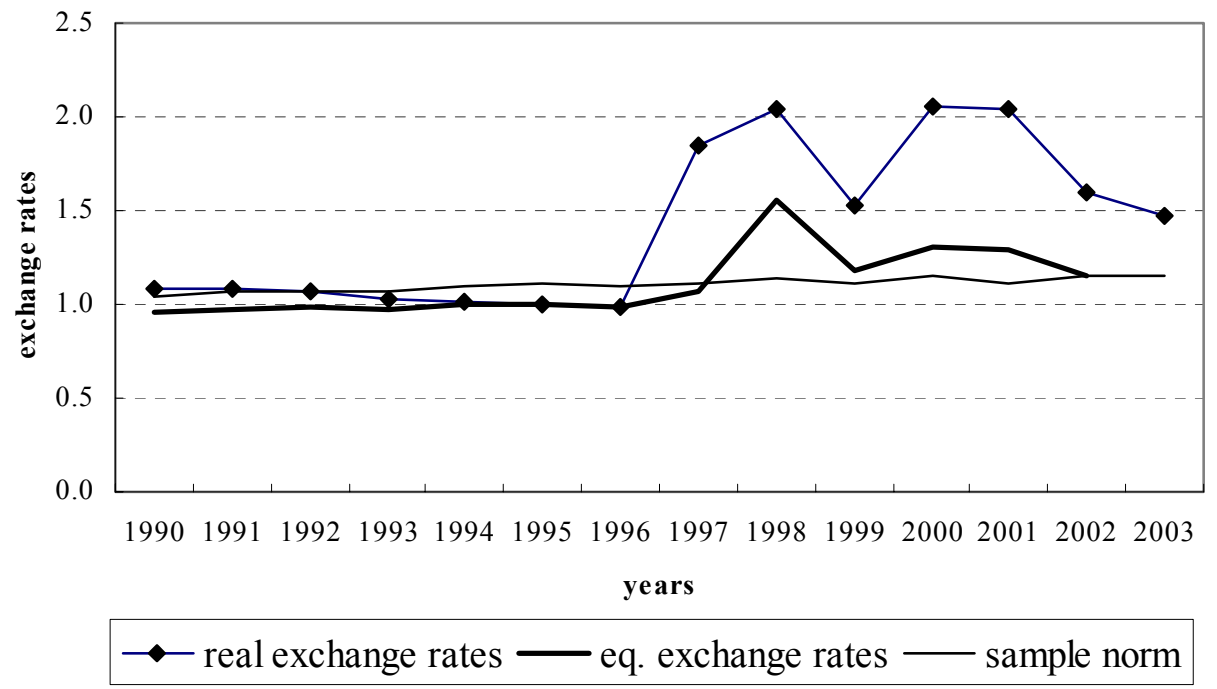


Figure 9. Real Exchange Rates for Korea

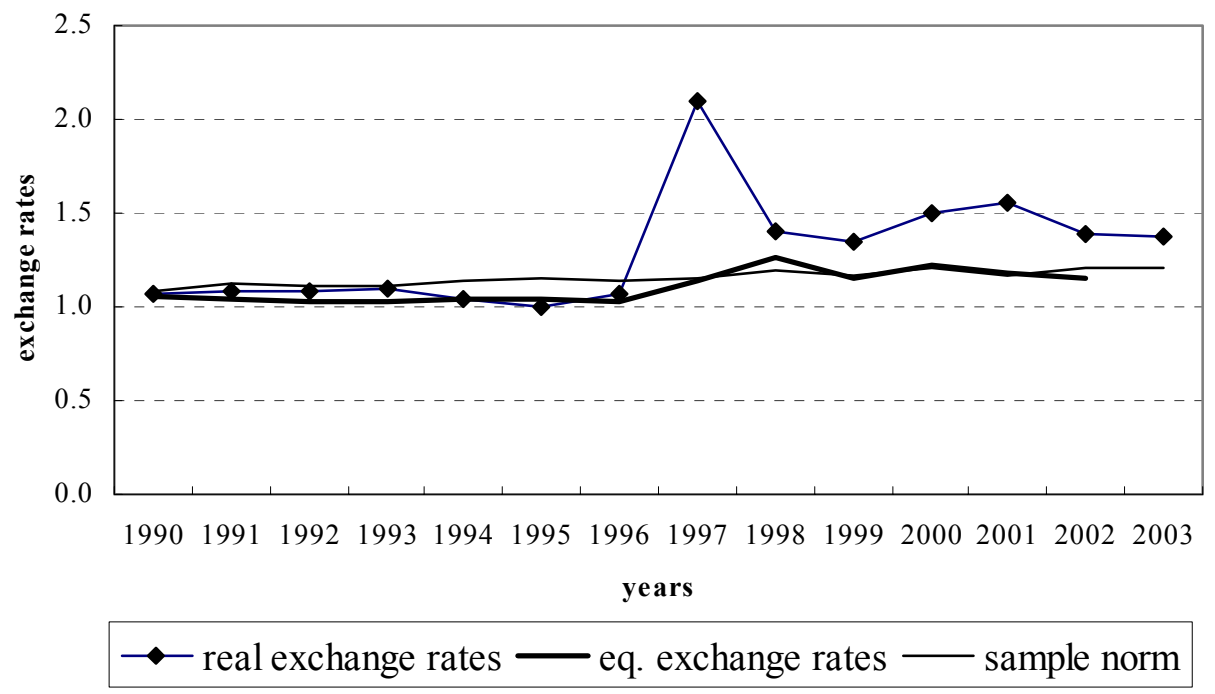

Figure 10. Real Exchange Rates for Singapore

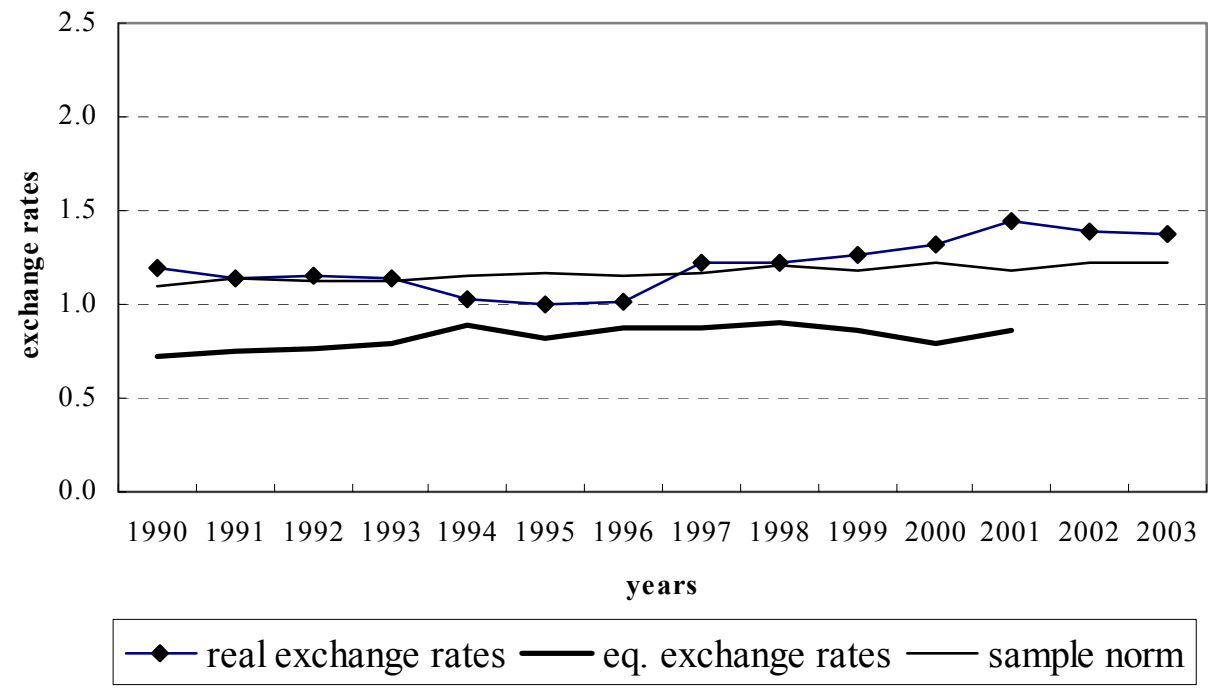


Figure 11. Real Exchange Rates for Thailand

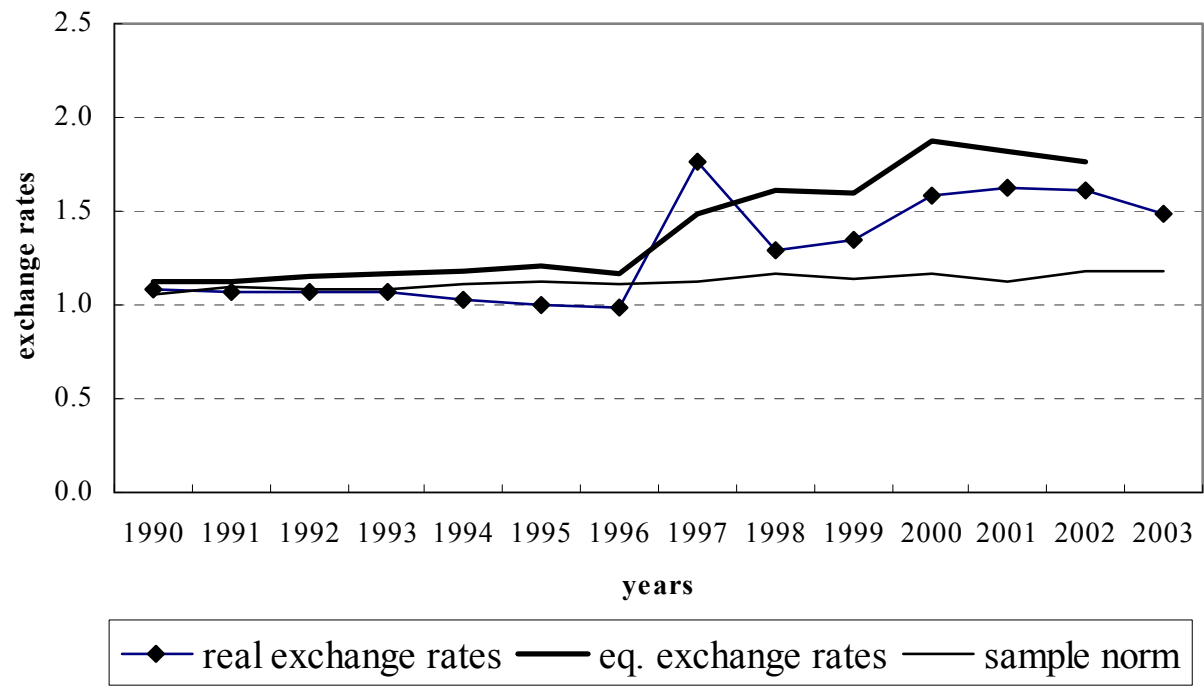




\begin{abstract}
Appendix
Most data is obtained from the World Bank's World Development Indicators (WDI) and the International Monetary Fund's International Financial Statistics (IFS). Data on exchange rates, price levels, and capital inflows come from IFS. Macroeconomic data on GDP, per capita GDP, gross fixed capital formation, government final consumption expenditure, imports, and exports are obtained from $W D I$.

Freedom House scores for political rights and civil liberties are available at http://www.freedomhouse.org. Polity scores for regime type can be found at the website for the Polity IV Project, http://www.cidcm.umd.edu/inscr/polity. Variables on the age structure of the population, per cent of population that is urban, and political risk are obtained from $W D I$.
\end{abstract}




\section{References}

Barcza, Gyorgy (2005), "Hungary: Domestic FX Borrowing Supports HUF," ING Emerging Markets Biweekly Report (4 February), pp.16-18.

Croke, Hilary, Steven B. Kamin and Sylvain Leduc (2005), "Financial Market

Developments and Economic Activity During Current Account Adjustments in Industrial Countries," International Finance Discussion Paper no. 827, International Finance Division, Board of Governors of the Federal Reserve System, Washington, D.C. (February).

Deutsche Bank (2005a), "Could Romania be the Next Slovakia?" Global Markets Research/Emerging Markets (13 April).

Deutche Bank (2005b), "Romania: Notes from Our Recent Visit," Global Markets Research/Emerging Markets (23 March).

Dreher, Axel and Roland Vaubel (2003), "The Causes and Consequences of IMF Conditionality," unpublished manuscript, University of Mannheim.

Edwards, Sebastian (2004), "Thirty Years of Current Account Imbalances, Current Account Reversals, and Sudden Stops,” NBER Working Papers no. 10276 (February).

Edwards, Sebastian (2005), "Is the U.S. Current Account Deficit Sustainable, and if Not, How Costly is Adjustment Likely to Be?” unpublished manuscript, UCLA (March).

Eichengreen, Barry and Molly Fifer (2002), "The Implications of Aging for the Balance of Payments Between North and South," in Horst Siebert (ed.), The Economics of Aging Societies, Kiel: Kiel Institute for World Economics.

Egert, Balazs (2004), “Assessing Equilibrium Exchange Rates in CEE Acceding Countries: Can We have DEER with BEER without FEER?" Institute for Economics in Transition Discussion Paper no. 1, Helsinki: Bank of Finland.

Goldstein, Morris (2002), Managed Floating Plus, Policy Analysis in International Economics no. 66, Washington, D.C.: Institute for International Economics.

Goldstein, Morris and Philip Turner (2004), Controlling Currency Mismatches in Emerging Markets, Washington, D.C.: Institute for International Economics.

Institute of International Finance (2005), "Capital Flows to Emerging Market Economies,” Washington, D.C.: Institute of International Economics (19 January).

Kalemi-Ozcan, Sebnem, Laura Alfaro and Vadym Volosovych (2003), "Why Doesn't Capital Flow from Rich to Poor Countries? An Empirical Investigation," Working Paper no. 2003-1, Department of Economics, University of Houston (December). 
Kim, B.Y. and I. Korhonen (2002), "Equilibrium Exchange Rates in Transition Economies: Evidence from Dynamic Heterogeneous Panel Models," Institute for Economics in Transition Discussion Paper no. 15, Helsinki: Bank of Finland.

Milesi-Ferretti, Gian Maria and Assaf Razin (1997), "Sharp Reductions in Current Account Deficits: An Empirical Investigation,” NBER Working Paper no.6310.

OECD (2004), Economic Survey of Hungary, Paris: OECD.

Pesaran, Hashem, Yongcheol Shin and Ron Smith (1999), "Pooled Mean Group Estimation of Dynamic Heterogeneous Panels," Journal of the American Statistical Association 94, pp.621-654.

Pesaran, Hashem, and Ron Smith (1995), "Estimating Long-Run Relationships from Dynamic Heterogeneous Panels," Journal of Econometrics 68, pp.79-113.

Schadler, Susan, Adam Bennett, and M. Carsovik (1995), "IMF Conditionality: Experience Under Standby and Extended Arrangements," IMF Occasional Papers no. 128 and 129.

Taylor, Mark and Lucio Sarno (1999), "Hot Money, Accounting Labels, and the Permanence of Capital Flows to Developing Countries: An Empirical Investigation," Journal of Development Economics 59, pp.337-364.

Valintinyi, Katalin (2003), "The Role of Foreign Banks in Five Central and Eastern European Economies,” Working Paper 2003/10, Budapest: National Bank of Hungary. 